\title{
Interactive English Teaching Model and the Cultivation of Higher Vocational Students' Communicative Language Abilities
}

\author{
Yang Li \\ Xiangyang Vocational and Technical College \\ Xiangyang, Hubei, 441021
}

\begin{abstract}
English is a language, which is not only to make students recognize and write them, but also to help them learn to speak and use them. It is obvious that traditional English teaching model neglects the cultivation of students' communicative language abilities, so this paper mainly analyzes how to apply interactive teaching mode of cultivating higher vocational students' communicative language abilities.
\end{abstract}

Keywords-Interactive English teaching model; Communicative language ability; Training strategy

\section{INTRODUCTION}

In recent years, as all the countries in the world keep closer and the cross-cultural communication is inevitable, it is very significant to improve higher vocational students' communicative language abilities under the background. However, traditional English teaching only pays attention to students' written test scores and overlooks the practical application of English, for the cultivation of students' communicative language abilities is not enough. Therefore, in the following part, we will focus on analyzing the interactive English teaching model and explore the correct way to use the interactive teaching model to cultivate higher vocational students’ communicative language abilities.

\section{ANALYSIS OF INTERACTIVE ENGLISH TEACHING MODEL}

Interactive English teaching mode refers to an interactive teaching model between teachers and students, students and students, which is formed by the equal and sincere communication, negotiation or discussion in the real English teaching activity. Interactive English teaching pattern is very different with the traditional English teaching mode. The latter is oriented with teachers' explanation and focused on the vocabulary memory and reading but neglects the practical application of English. As a result, students can know all the English words and reading but they can't speak English. Such teaching mode is obviously not correct and comprehensive, which not only does not meet the social requirements for English teaching, but also has an impact on students' overall development. Compared with the traditional English teaching mode, interactive English teaching model pays more attention to develop students' communicative ability of language, focused on the teaching of English oral practice and making students dare to speak English and improving students’ English communicative ability through the interaction of two or more sides. It can be seen that the interactive English teaching model is more in line with the requirements of contemporary English teaching. In the following part, we will analyze the teaching characteristics of the interactive English teaching model in detail.

The first is to emphasize the two-way initiative between teachers and students. For a long time, we often hear such words like "adjusting students' initiative”. It is important to adjust students' initiative and enthusiasm and let students have enthusiasm with learning English, but it is also vital to adjust teachers' initiative. Teacher is the main guide in the teaching activities. Teachers' teaching attitude and emotion have a direct impact on students' learning status. If teachers are in a bad mood, lacking enough teaching enthusiasm and initiative, then students will be affected by teachers' teaching status, leading to low learning efficiency. Therefore, the initiative in English learning should not be the one-way initiative of students, but the two-way initiative between teachers and students. It is exactly the contents that are emphasized in interactive English teaching pattern. It can make teachers have full communication with students through the interaction between teachers and students, students and students. They can have negotiation and discussion on the existing related problem in the teaching process. The equal experience can not only arouse the enthusiasm of students, but make teachers feel refreshed. In addition, teachers played the role of answering students' confusion and questions in the former teaching activities, but they have little understanding with students' thought and viewpoints. Teachers can make more in-depth understanding of students' learning situation and students' thoughts through the interactive process, to let teachers have a new understanding with their teaching logics and ideas so as to raise teachers' initiative. Meanwhile, students' questions can be timely solved through the communication and interaction with teachers. Students' ability of independent thinking, corresponding ability and innovative thoughts can be greatly trained under the guidance and encouragement of teachers. What's more, their learning initiative and enthusiasm will be higher.

Secondly, the interactive English teaching mode emphasizes the two-way influence between teachers and students. Scientific and effective teaching activities should be a two-way interaction and influence between teachers and students. Teachers' teaching behaviors will affect the students, 
and students' learning activities will affect teachers. In the traditional teaching mode, teachers occupy the dominant position in teaching activities. Their thoughts and views even influence students' thoughts. Therefore, it is difficult for teachers to pay attention to some valuable opinions of students. Such teaching will not only affect students' initiative in learning, but also hinder the development of students' innovative thinking. In the interactive English teaching model, teachers and students can discuss and debate on the same topic or issue. In the process of discussion and debate, students and teachers are equal. Teachers respect students' ideas and views, and students also carefully think about teachers' viewpoints on this issue. So, the ideas and thoughts of teachers and students are influenced by each other. Their thoughts will seek some synergy in virtually to realize the convergence of ideas. In addition, in the process of interaction, teachers and students will think, participate and cooperate together with the question needed to be discussed, and they will have the psychological resonance on this question to achieve mutual influence and promotion through the sharing of thoughts and ideas.

\section{SPECIFIC APPLICATION OF INTERACTIVE ENGLISH TEACHING MODEL}

In the application of interactive teaching mode to cultivate students' ability of language communication, the interaction between students and teachers must be paid attention to. Help students dare to and be able to speak English through the communication of two or more sides so as to improve students' communicative language abilities. We will connect specific teaching case to study the measures of using interactive teaching mode to train students' communicative language abilities.

\section{A. Grasp English class and implement classroom interaction}

Classroom is the main place for students to acquire English knowledge and the most important place for interactive English teaching mode to play a role. Therefore, teachers should reasonably plan the classroom, achieve the interaction in the classroom and improve students' English communication ability through effective interaction in the classroom. So, English teachers should do the following two aspects: one is the reasonable planning of classroom teaching time. Interactive teaching does not mean that the chaos of the classroom order. It does more harm than good if the English class is out of order because of the interaction of teachers and students, students and students. So, teachers should have a rational plan with teaching and interaction time in the class when they prepare to use interactive English teaching mode. Rationally divide class teaching time according to the English learning condition and clearly plan teaching time, students' autonomous practice time and the interaction time between teachers and students, students and students. Create an orderly class for students through reasonable plan to make students follow teachers' teaching ideas. The second one is to pan the interaction part. The class interaction should have an order, which doesn't mean the interaction time is fixed. On the contrary, it should be operated through the whole teaching, for instance, teachers guide students to talk their learning difficulties before the class, and teachers can have a discussion about these difficult problems with students. In the process of class, teachers can use the method of asking and answering to interact with students. They can also conclude the learning content of this class and discuss students' conclusion, guiding students to compare their conclusions with others to make leak filling. In addition, teachers can flexibly apply the textbook content, organize students to conduct situational dialogues and enhance the interaction with students. For example, teachers can organize students to play different task roles and arrange a life situation, which can be foreigners' asking the way or the introduction of your family to foreigners so as to guide students to communicate in English and train communicative language ability through good learning atmosphere.

\section{B. Conduct class debate}

Debate is the most effective way to cultivate the students' communicative language abilities, especially in the condition of students' English foundation and language application ability being weak, teachers should connect specific teaching activities and organize students in the class to have a debate on some problem and improve students' communicative language abilities through the debate. The debate form should be diversified in the practical teaching application. It can be the debate within the group or the class. Specific debate form should depend on the specific teaching condition. But it is certain that debate is one of the indispensable links when the interactive teaching mode is applied to train students' communicative language abilities. And English debate should be used through the whole learning. Debate practice with once or twice cannot receive practical practice effect. It should be persistent. Use debate practice of long time to train students' communicative language abilities. The theme of the debate can be encountered difficulties in class or some open questions in the English teaching materials, and it can also be some hot topics in society. Teachers should rationally ensure the topic of the debate and correctly grasp the difficulty level of debate based on students' English learning condition and English communication ability, avoiding the condition that the difficulty level of debate content is too big or small so that the debate loses its meaning. Therefore, it is necessary for English teachers to have a long-term plan on the teaching strategy of debate, so as to ensure that the debate will be from easy to difficult, and to improve students' communicative language abilities step by step.

\section{Use English songs to conduct various forms of interactive teaching}

Interactive English teaching mode is not fixed in a specific teaching form. It is flexible and its teaching method is also flexible. Therefore, English teachers are supposed to correctly grasp the application point when using interactive English teaching mode to cultivate the students' language communicative ability, avoiding making interactive English teaching model limited in a narrow range and influencing the teaching effect. So, teachers can flexibly use various interactive teaching methods in the practical teaching process to train students' communicative language abilities, for example, carry out the interactive teaching through English songs to cultivate students' communicative language abilities. English is a language as well as an art. You can enjoy English words with 
simple humming of melody. Therefore, many students nowadays like to listen to English songs in their spare time. English teachers can make full use of this hobby and organize students to interact around English songs. Now most of the songs in English pronunciation is very accurate and clear, so it is easy for students to learn, and the own characteristics of songs and repeated appearance of some English words in the songs are more conductive to students' pronunciation learning. Many English songs have many repeated words, and each of them is very standard and clear, for instance, "You don't have to say I love you to say I love you" and "All I need is you”, are very easy to imitate both the pronunciation and the lyrics for they are seen again and again. Teachers can organize students to have English songs practice before the class or after the class, in the form of singing or memorizing the lyrics. Let students choose a partner to sing English songs together in the group and let other students in the group find the problem of pronunciation or others and discuss the solving methods together. Under the help of students, students' English pronunciation can be effectively corrected and the cooperation among students can be strengthened at the same time of improving communicative language ability, which is good for the perfect atmosphere forming of speaking English within the class and helping students train the communicative language ability.

\section{Create a large interactive environment.}

Learning environment has an important influence on students' learning, so the use of interactive English teaching mode to cultivate the students' communicative language abilities cannot be limited in the classroom interaction and the interaction between students and teachers. Schools and teacher should effectively use teaching resources to create a more interactive environment for the students and provide more excellent interactive resources for students, which is helpful to improve their communicative language abilities under the big English environment. It can be seen from the analysis of many current English teaching status in our country, English learning are more likely to the learning on the paper and do reading and memorizing English words are to get good grades in English tests. It is rare to create a big English learning environment for students in usual teaching process, for example, English teaching is oriented with Chinese teaching and supplemented with communication in classroom English teaching. Students rarely use English dialogue out of class. In the long learning process, both students and teachers deviate from the center of English learning and ignore English itself. So, school can advocate capable teachers in the school to interact and communicate with students in English as far as possibly in the daily teaching and guide students to communicate in English in their daily life so as to make communicative language ability get effective exercise. Those schools with the condition can establish relevant cooperation with foreign colleges and universities and encourage students more participate in international cultural exchange activities and contact with students under different cultural backgrounds and improve their communicative language abilities through the communication and interaction among different cultures and languages.

\section{CONCLUSION}

To sum up, the application of interactive English teaching model can effectively develop the students' communicative language abilities, so English teachers should continuously explore in the teaching practice and conclude the most effective application strategy and improve students' communicative language abilities

\section{REFERENCES}

[1] Yang Qianqian. The cultivation of interactive English teaching mode and students' communicative language abilities[J]. Modern Communication, 2018(01):98-99+97.

[2] Dai Zhihua. Analysis on the implementation of interactive English teaching[J]. Journal of Jiang xi Electric Power Vocational and Technical College, 2014, 27(03):72-75.

[3] Gao Jing. Use the debate to activate college English classroom teaching[J]. Foreign Language Researching World, 2012, 1(00):253-261.

[4] Chen Jingyan. Discussion on the interactive English teaching[J]. Technology and Information, 2010(31):430-431.

[5] Li Guangfeng. Optimize English teaching model to promote students' independent development -- an interactive English teaching model based on multimedia and network[J]. Education Theory and Practice, 2009, 29(34):59-61.

[6] Li Xiaoying. Features of Danish business English classroom teaching feeling after visiting Niels Brock Business School in Denmark[J]. Foreign Language Education in China, 2009, 2(03):43-47+73. 